\title{
Ground-penetrating radar measurements of 64 Austrian glaciers between 1995 and 2010
}

\author{
Andrea FISCHER, ${ }^{1}$ Michael KUHN ${ }^{2}$ \\ ${ }^{1}$ Institute for Interdisciplinary Mountain Research, Austrian Academy of Sciences, Innsbruck, Austria \\ E-mail: andrea.fischer@uibk.ac.at \\ ${ }^{2}$ University of Innsbruck, Innsbruck, Austria
}

\begin{abstract}
The ongoing retreat of mountain glaciers necessitates the development of future scenarios of glacier runoff. These scenarios are not only governed by future climate scenarios influencing glacier mass balance but also by the glacier volumes, which are subject to melt. Ground-penetrating radar (GPR) is a valuable tool for measuring the thickness of mountain glaciers, although ground-based measurements are labour-intensive, so not all glaciers can be surveyed. This study presents the results of GPR surveys on 64 Alpine glaciers, carried out between 1995 and 2010. The glacier areas range from 0.001 to $18.4 \mathrm{~km}^{2}$, and their ice thickness was surveyed with an average density of 36 points $\mathrm{km}^{-2}$. The point measurements were extrapolated manually to derive volume maps. The mean ice thickness varies between 10 and $92 \mathrm{~m}$; the maximum ice thickness is about three times the mean thickness. According to the glacier state recorded in the second glacier inventory, the 64 glaciers cover an area of $223.3 \pm 3.6 \mathrm{~km}^{2}$, with a mean thickness of $50 \pm 3 \mathrm{~m}$ and a glacier volume of $11.9 \pm 1.1 \mathrm{~km}^{3}$. The mean maximum ice thickness is $119 \pm 5 \mathrm{~m}$.
\end{abstract}

\section{INTRODUCTION}

The recent retreat of the world's glaciers (e.g. Lemke and others, 2007) affects hydrology on a local, regional and global scale (e.g. Arendt and others, 2002; Jansson and others, 2003; Kuhn and Escher-Vetter, 2004; Raper and Braithwaite, 2006; Casassa and others, 2009; Kaser and others, 2010; Radić and Hock, 2011). On a global scale, the runoff from mountain glaciers contributes to global sealevel rise. Regionally, the total amount and seasonality of the glacier runoff may change, with implications for water management, irrigation and energy production. Locally (e.g. in the European Alps), the glaciers as characteristic features of the landscape play a role in summer and winter tourism (Fischer and others, 2011). The possible disappearance of Alpine glaciers and the timescale for this (Zemp and others, 2006; Huss and others, 2008) are discussed with respect to all the issues mentioned above.

To monitor the past and current glacier changes, glacier areas, volume changes and mass balances are recorded using different methods. Glacier volume is an important initial condition for assessing further glacier retreat (Farinotti and others, 2009a). Furthermore, the total glacier volume is equal to the maximum potential contribution to sea-level rise. The pace of glacier retreat is not only governed by atmospheric conditions that influence mass balance, but also by the distribution of ice within the glacier, which controls the area loss and thus the area contributing to further ice melt.

Several glacier inventories include glacier volumes (e.g. Müller and others, 1976, 1977; WGMS, 1989), which are partly estimated or modelled. For the 1998 Austrian glacier inventory (Lambrecht and Kuhn, 2007; Kuhn and others, 2009, 2012), GPR measurements were carried out for two reasons: (1) to include measured volume data and (2) to improve the calculation of glacier volumes of unmeasured glaciers by surveying glaciers that are representative for all Austrian glaciers in terms of area, type, aspect and specific regions and slope. Ice thickness measurements started in
1995. Since ground-based measurements turned out to be labour-intensive and restricted by field conditions, the most recent surveys were carried out in 2010, 8 years after the previous data acquisitions for the glacier inventory. Of the 896 Austrian glaciers, 64 were measured (Kuhn and Fischer, 2012). To calculate the bedrock elevation from measured ice thickness data, digital elevation models (DEMs) of the glacier surface were used, which date from 1996-2002. Compilation of a third Austrian glacier inventory (GI III) is under way (Abermann and others, 2009, 2012; StockerWaldhuber and others, 2012), so that surface elevation changes before and after the second glacier inventory (GI II) and the radar survey can be estimated.

So far, several studies have been published describing specific aspects of the GPR measurements within GI II: the method for deriving point ice thickness and most of the measured point data is summarized by Span and others (2005) and Fischer and others, (2007). In a case study of one of the best-surveyed glaciers, Schaufelferner in the Stubai Alps, Fischer (2009) described different interpolation methods to calculate ice thickness for the total glacier area. Kuhn and Fischer (2012) summarized preliminary results for glacier volumes in the context of the 1998 glacier inventory.

In this paper, technical aspects, methods and assumptions are presented, with a rough assessment of the accuracy of the resulting ice volumes.

\section{METHOD}

\section{Point ice thickness measurements}

Ice thickness measurements were carried out with the transmitter developed by Narod and Clarke (1994) combined with resistively loaded dipole antennas (Wu and King, 1965; Rose and Vickers, 1974) at central wavelengths of 6.5 (30 m antenna length) and $4.0 \mathrm{MHz}(50 \mathrm{~m}$ antenna length). The signal was recorded trace by trace with an oscilloscope. Examples of signals are provided in Figure 1, showing traces recorded at Schaufelferner in August 2006. 

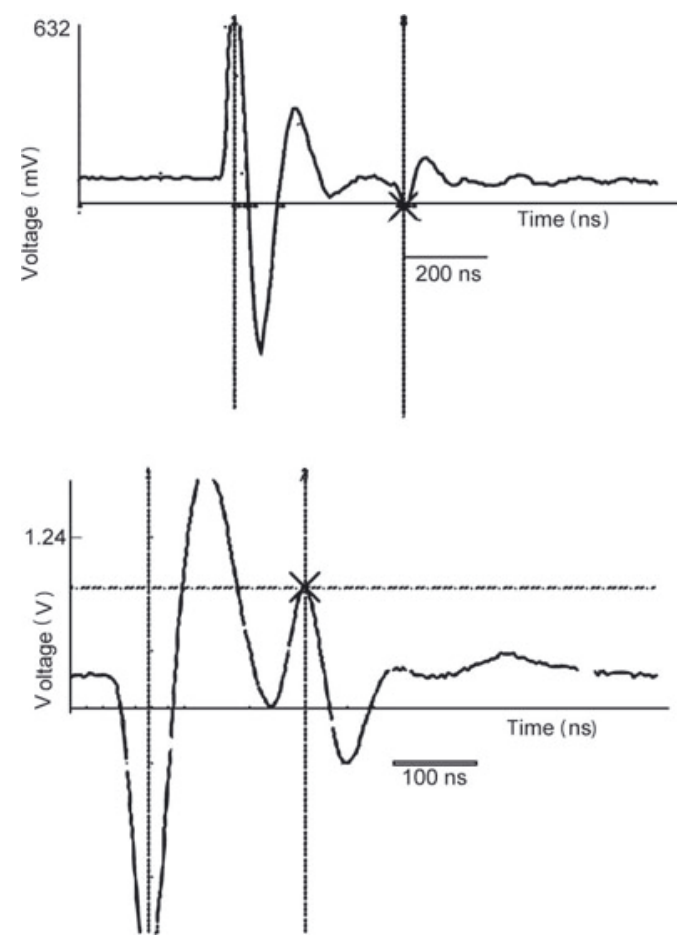

Fig. 1. Examples of GPR point records recorded with the Fluke 105 B oscilloscope on Schauferner in 2006.

The point ice thickness, $h_{\mathrm{p}}$, was calculated for each measurement assuming a homogeneous plane-parallel ice block:

$$
h_{\mathrm{p}}=\frac{1}{2} \sqrt{\left(\Delta t+\frac{1}{c_{\mathrm{a}}}\right)^{2} c_{\mathrm{i}}^{2}-a^{2}},
$$

where $\Delta t$ is the time difference between the direct and reflected signal and $a$ is the antenna separation. The signal

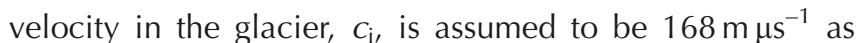
used by Haeberli and others (1982), Narod and Clarke (1994) and Bauder (2001), and the signal velocity in air, $C_{\mathrm{a}}$ is assumed to be $300 \mathrm{~m} \mathrm{\mu s}^{-1}$.

At the time of the measurements, the glaciers were covered with winter snow. In the accumulation area, firn cover existed until 2003 but then decreased sharply, with extremely high melt rates even at high elevations. Since the amounts of snow and firn cover vary for the specific measurement locations, and neither layer-thickness nor common-midpoint measurements been carried out frequently, the glacier was assumed to consist of ice when calculating the ice thickness with Eqn (1).

The measurement positions were recorded with a handheld GPS with a nominal accuracy of 5-30 m depending on the number and position of satellites. Typically, the point measurements were located along several profiles across the glacier and, at the location of the maximum depth, along the glacier, with the aim of finding the maximum ice thickness. Examples of measured data are shown for Taschachferner and Mittelbergferner, Ötztal Alps, in Figure 2.

\section{Data interpolation}

The point measurements were interpolated to calculate the total glacier volume. As shown in Figure 2, the measured point data are often sparse and unequally distributed over the glacier. Additional information is drawn from the natural boundary condition that the ice thickness is zero at the glacier margins. However, in regions with sparse data, automatic interpolation with algorithms (e.g. kriging, inverse distance weighting (IDW) or spline) produces ice thickness maps that deviate considerably from what can be expected from an educated guess. For example, crevassed areas can indicate discontinuities in the bedrock, and ice thickness in steep areas is usually smaller than in neighbouring flat areas. Furthermore, slopes of side-walls exposed during recent

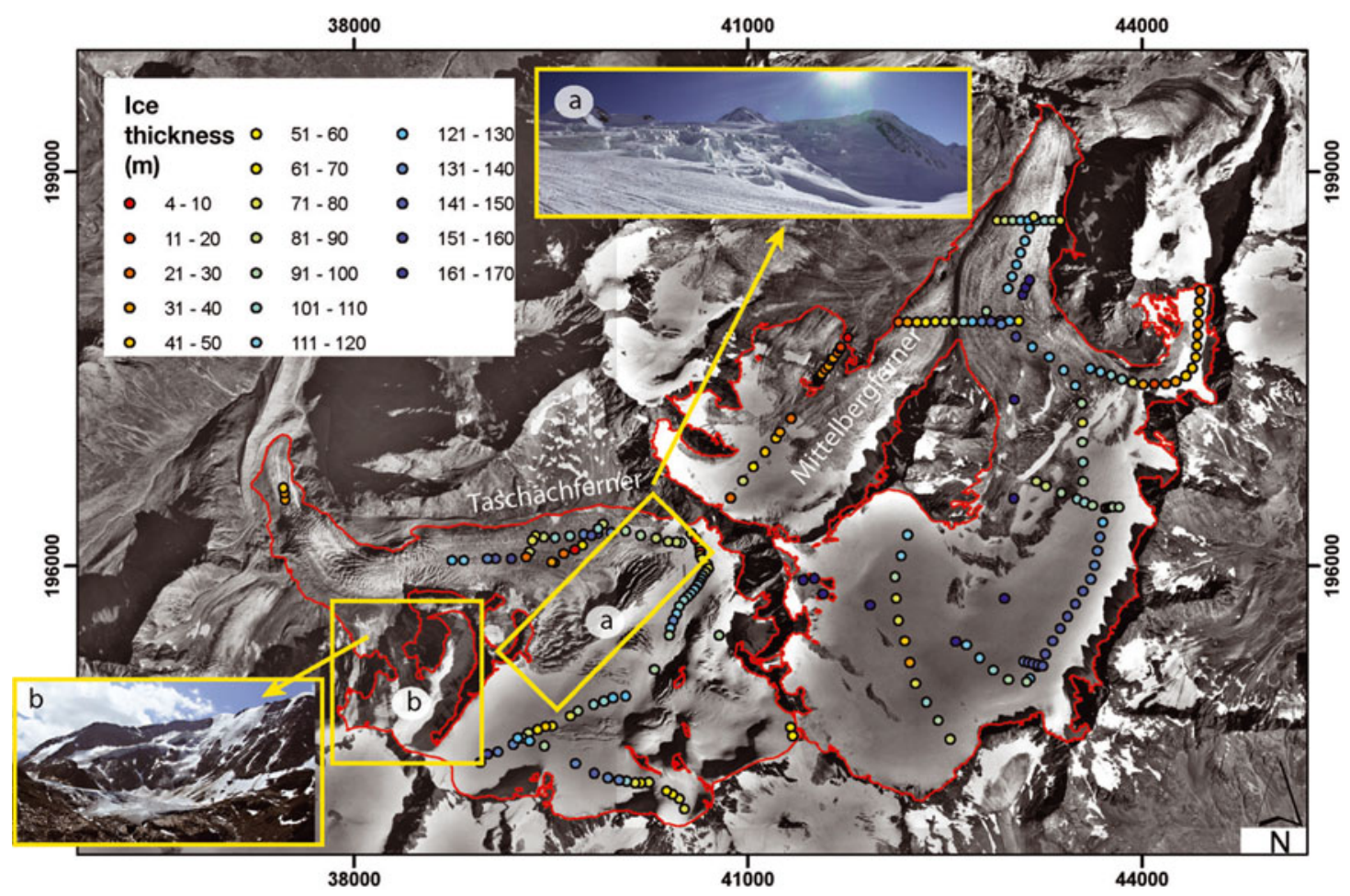

Fig. 2. Spatial distribution and results of ice thickness measurements for Mittelbergferner and Taschachferner in the Ötztal Alps. Data gaps on Taschachferner result from large crevasse zones and steep areas (small photographs). 


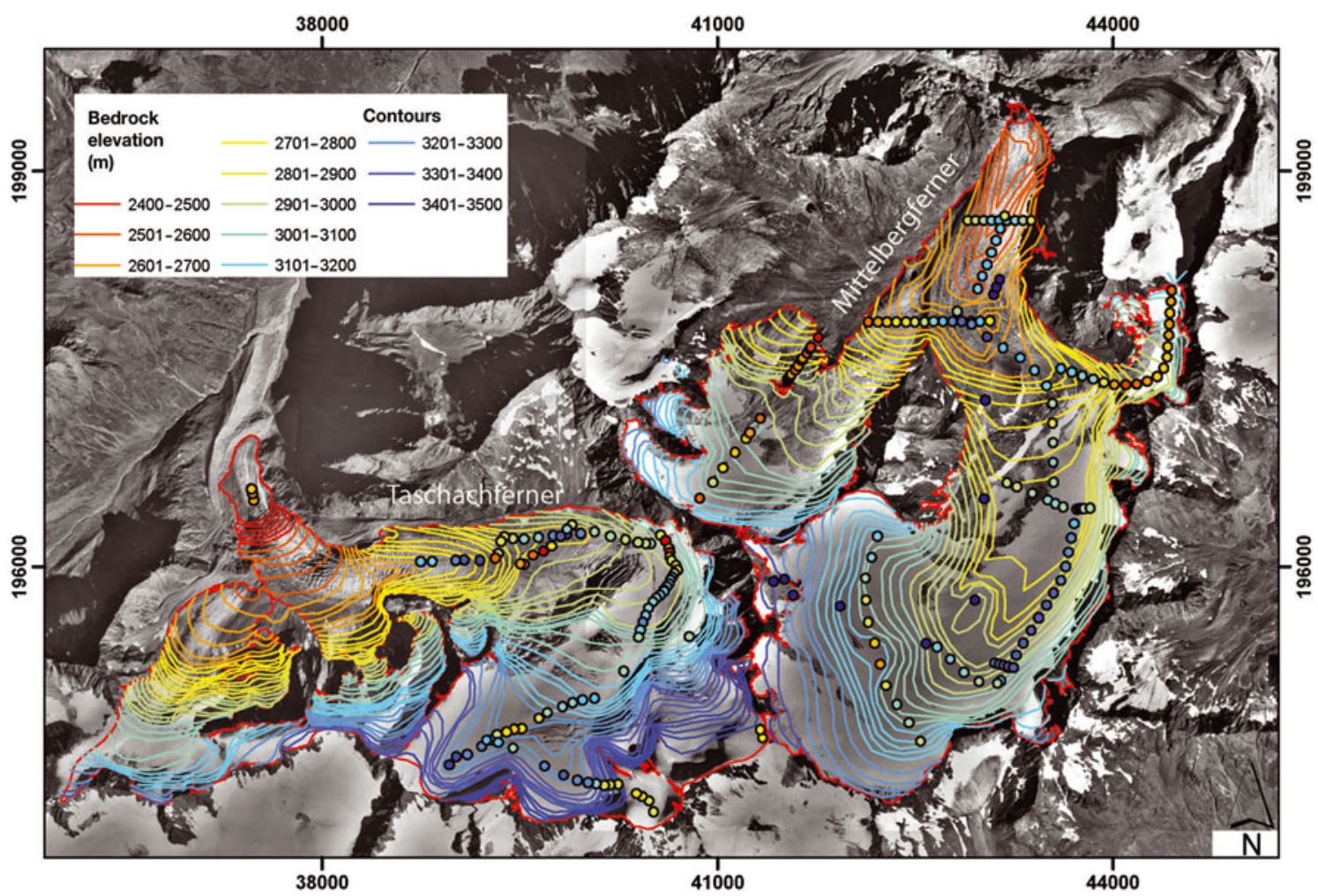

Fig. 3. $20 \mathrm{~m}$ contours of subglacial topography manually interpolated from the ice thickness measurements of Taschachferner and Mittelbergferner.

glacier retreat often suggest a constant slope, so the slope of the rocks surrounding the glaciers also provides information on the still ice-covered slope of the glacier bed. For hanging glaciers, the ice thickness at the front is apparent from the DEM of the glacier surface and the bedrock beneath. This information can be included, either by introducing artificial points for use in spatial interpolation algorithms or during manual construction of contours.

Another possibility is to interpolate measured data with the help of ice-dynamical models (e.g. Binder and others, 2009; Farinotti, 2009b). As the point data available for this study show inhomogeneous spatial distribution, and the method applied should be the same for every glacier, no such models have been used. Instead, $20 \mathrm{~m}$ contours of bedrock elevation were manually drawn (Fig. 3) for Taschachferner and Mittelbergferner according to point measurements and the following additional rules:

1. the ice thickness at glacier margins is zero

2. crevassed zones indicate ice thickness smaller than surrounding areas without crevasses

3. the slope of the surrounding bedrock indicates the slope of neighbouring ice-covered bedrock

These contours were then interpolated with the ArcGIS tool 'topo 2 raster' on a $5 \times 5 \mathrm{~m}^{2}$ grid (Fig. 4). The topo2 raster tool is based on the ANUDEM algorithm developed by Hutchinson (1989). The ice thickness was then derived by subtracting the bedrock elevation DEM from the surface elevation DEM (using the ArcGIS tool 'Minus'). The $z$-values of the nodes of the shapes of the glacier areas (without ice divides) were set to the value of surface elevation DEMs. Due to the difference between raster cells and node positions, the topo2raster interpolation often results in slightly negative ice thickness values. This was corrected by reclassification of these cells to an ice thickness of $2 \mathrm{~m}$. The mean ice thickness, $h$, was calculated as the mean of the ice thickness, $h_{N}$, at all $N$ gridcells, and the maximum ice thickness as the maximum of all gridcells. The volume, $V$, of a specific glacier was calculated by multiplying the mean ice thickness, $h$, by the glacier area, $A$.

Since all the volume data are intended for use in the glacier inventory, the area was taken from the glacier inventory even though the area changed between the GPR measurement and the date of the inventory. Thus the area assumed at the time of the measurements is too large, resulting in overestimation of the ice volume.

\section{Uncertainty analysis}

A rigorous and complete assesment of all errors and the uncertainty of the presented data based on sparse measurements would require a more thorough knowledge of a 'true value'. What can be done to allow at least an estimate of the reliability of the presented volumes is an uncertainty analysis of (1) case studies and (2) the specific components leading to the results at point and glacier-wide level.

Calculation of the volume involves deriving the mean ice thickness for the glacier area by extrapolating the point measurements, and multiplying it by the glacier area. Thus the uncertainty involved in these two steps must be investigated.

\section{Uncertainty of point ice thickness measurements}

The ice thickness at one measurement location is calculated using Eqn (1) and involves mainly the following uncertainties:

1. the uncertainty of the signal velocity in the glacier, mainly due to the neglected firn and snow layers 


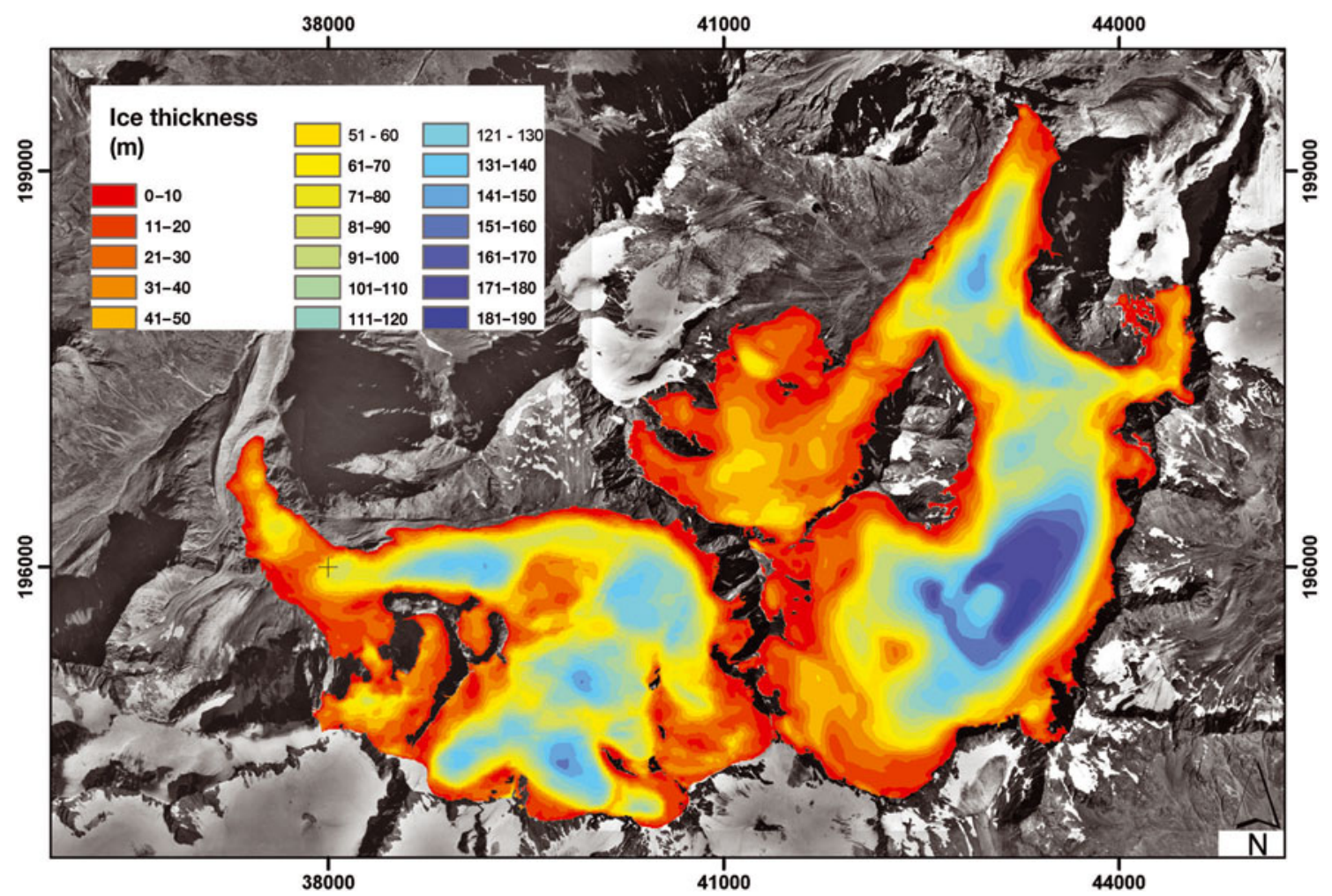

Fig. 4. Map of ice thickness of Taschachferner and Mittelbergferner calculated with the topo2raster tool.

2. the accuracy of the oscilloscope reading

3. the uncertainty of the antenna separation

4. unknown point of bedrock reflection

5. interpretation of multiple reflections.

Most of the measurements were carried out in winter, when the glacier was under seasonal snow cover. In the absence of a well-defined summer melt layer, snow probing does not allow the height of snow cover to be gauged, especially in the accumulation area. Thus the seasonal snow cover adds to the glacier thickness, in an order of 2 to $\sim 6 \mathrm{~m}$. Neglecting the signal velocities in firn $\left(\sim 200 \mathrm{~m} \mathrm{ss}^{-1}\right)$ and snow $\left(\sim 290 \mathrm{~m} \mathrm{ss}^{-1}\right)$ in Eqn (1) leads to an underestimation of ice thickness (Fig. 5) of up to $7 \mathrm{~m}$, assuming a firn cover of $30 \mathrm{~m}$ and a snow cover of $5 \mathrm{~m}$. In the case of

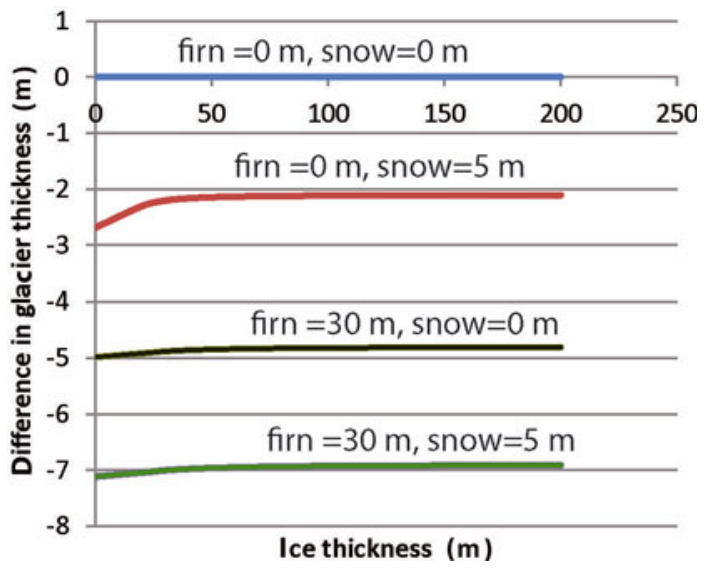

Fig. 5. Neglecting differences in signal velocities between ice, firn and snow leads to underestimation of the glacier thickness. winter snow cover, the overestimation of glacier volume by including the snow cover and the underestimation of the volume caused by the bulk velocity assumption can cancel each other out.

The accuracy of the oscilloscope reading depends on the ice thickness and is estimated at $\sim 30 \mathrm{~ns}$ with the Fluke $105 \mathrm{~B}$ oscillosope. The effects of uncertainties 3-5 on the accuracy can be high locally, especially on steep slopes, small and deep glacier tongues or in very rough bottom topography, so they are not considered further here. Overall, the uncertainty of point ice thickness measurements is assumed to be $5 \%$, as the spatial interpolation method is regarded as the main uncertainty.

\section{Uncertainty of data interpolation}

The ice thickness was interpolated manually, after different interpolation methods had been tested in a case study for Schaufelferner. Schaufelferner has been surveyed several times with high data density, and the volume derived by manual contouring from the sparse GPR data was similar to the high-resolution volume. Automatic spatial interpolation algorithms (e.g. kriging, spline, natural neighbour or IDW) produce zero or negative ice thickness in areas where no measurements are available. Figure 6 shows examples for Mittelbergferner and Taschachferner. Geostatistical interpolation results in significantly underestimated volumes and mean ice thicknesses (Table 1). Even when the interpolation parameters can be optimized in the example, the ice thickness remains high close to GPR point measurements and decreases in unmeasured areas to zero. Averaging the GPR-measured ice thickness biases the volume towards higher values, since flat and central parts of the glacier show higher data density than crevassed and steep areas (Table 1). For both glaciers, the average of the mean ice thickness is $45 \mathrm{~m}$ and the results of all spatial interpolation algorithms 
Table 1. Results of different methods to derive the mean $\left(h_{\text {mean }}\right)$ and maximum $\left(h_{\max }\right)$ ice thickness, with standard deviation of the ice thickness

\begin{tabular}{|c|c|c|c|c|c|c|}
\hline & \multicolumn{3}{|c|}{ Taschachferner (94 GPR point meas.) } & \multicolumn{3}{|c|}{ Mittelbergferner (182 GPR point meas.) } \\
\hline & $h_{\text {mean }}$ & $h_{\max }$ & std dev. & $h_{\text {mean }}$ & $h_{\max }$ & std dev. \\
\hline & $\mathrm{m}$ & M & $\mathrm{m}$ & $\mathrm{m}$ & $\mathrm{m}$ & $\mathrm{m}$ \\
\hline Topo2raster & 58 & 153 & 40 & 61 & 188 & 48 \\
\hline Kriging & 24 & 134 & 38 & 35 & 170 & 43 \\
\hline IDW & 23 & 161 & 39 & 30 & 151 & 42 \\
\hline Spline & 36 & 2000 & 117 & 34 & 218 & 47 \\
\hline Natural neighbours & 31 & 161 & 39 & 38 & 150 & 39 \\
\hline Mean GPR thickness & 95 & 162 & 36 & 75 & 152 & 42 \\
\hline
\end{tabular}

are within $50 \%$ of the mean. This value can be considered the upper limit of uncertainty in mean ice thickness resulting from different data interpolation algorithms.

The same interpolation algorithm was used for all glaciers. The mean uncertainty of measured ice thickness was estimated to be 5\% (Fischer, 2009). Nevertheless, the main source of uncertainty in mean ice thickness is the unmeasured areas, since the mean ice thickness is calculated as the mean of all gridcells. Some gridcells are located close to measured values or known ice thickness (e.g. at the margins, where the ice thickness is zero), and should return lower uncertainties than those not surveyed. Assuming that one measured point represents a $250 \times 250 \mathrm{~m}^{2}$ area with $5 \%$ uncertainty, an area-weighted mean uncertainty was calculated for the total glacier area assuming that the uncertainty in unmeasured areas is $50 \%$.
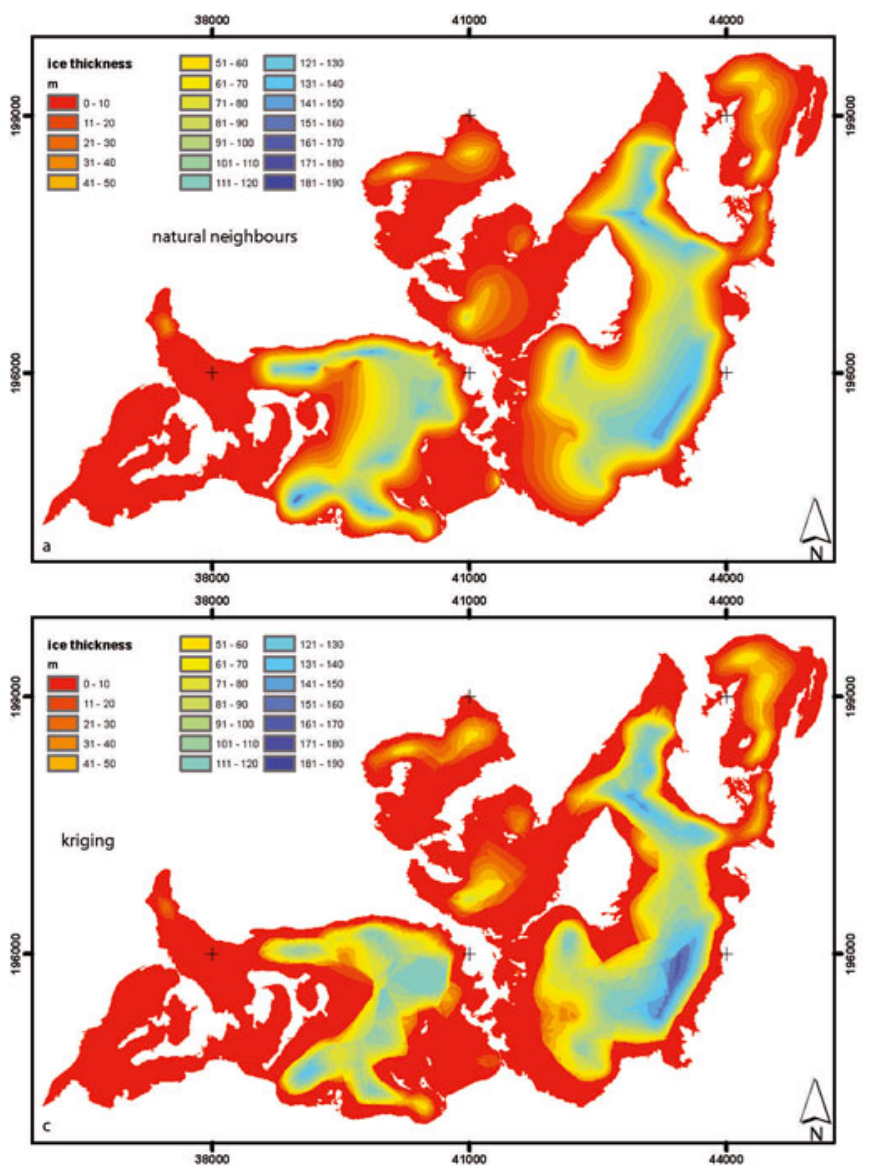

\section{Uncertainty of resulting volume}

The uncertainty, $\sigma_{V}$ of the volume, $V$, is determined by the uncertainties, $\sigma_{h}$, of the mean ice thickness, $h$, and the uncertainties, $\sigma_{A}$, of the area, $A$.

The area change between the date of the GPR measurement and the date of the glacier inventory was corrected assuming mean ice thickness for the lost area.

For glaciers not included in GI III so far, a mean decadal area change of $15 \%$ and a mean annual surface elevation change of $-0.3 \mathrm{~m} \mathrm{a}^{-1}$ were assumed for the years between the first glacier inventory (GI I) and GI II, and $-0.9 \mathrm{~m} \mathrm{a}^{-1}$ thereafter. Thus, the overall uncertainty of the glacier volume is

$$
\frac{\sigma_{V}}{V}=\sqrt{\left(\frac{\sigma_{h}}{h}\right)^{2}+\left(\frac{\sigma_{A}}{A}\right)^{2}}
$$
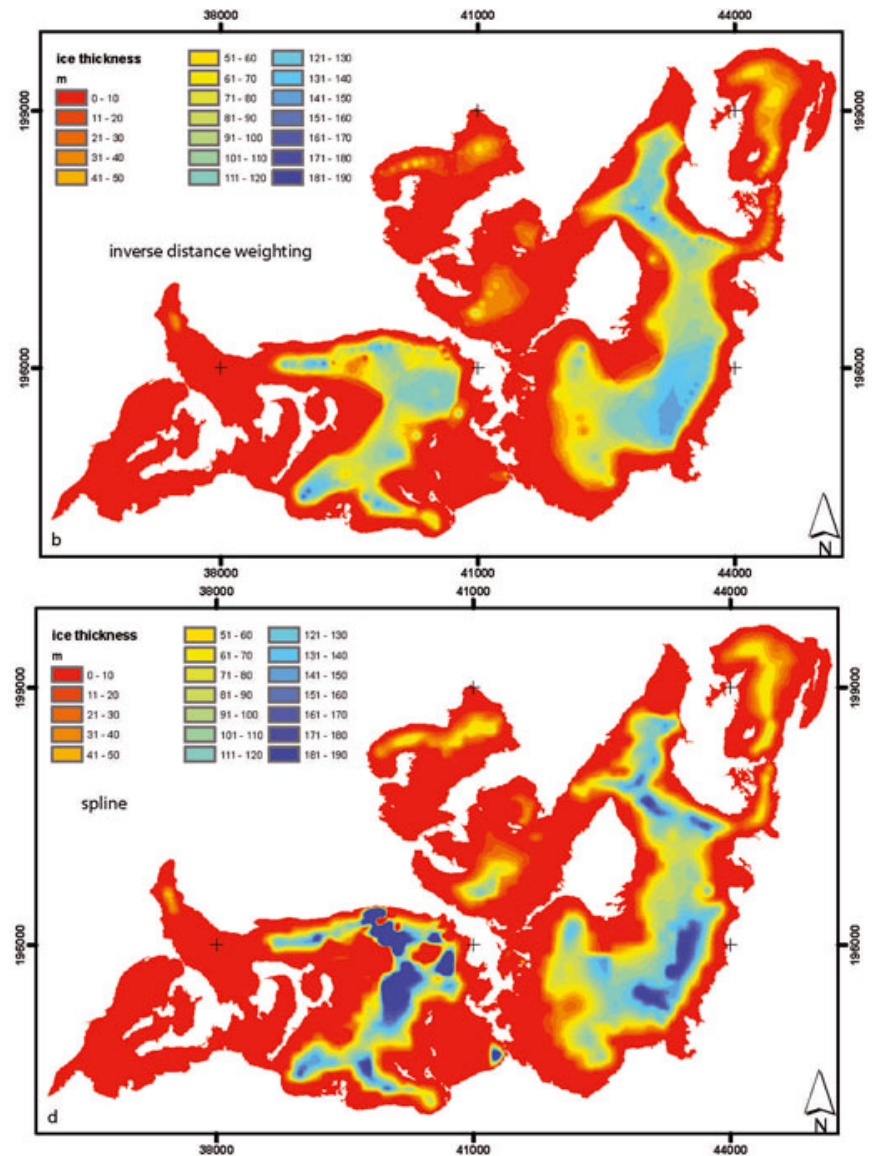

Fig. 6. Spatial interpolation algorithms as natural neighbours (a), IDW (b), kriging (c) and spline (d) underestimate ice thickness in unmeasured areas. 
Table 2. List of surveyed glaciers with year of survey, number of point measurements (\#), point measurements per square kilometre, year of glacier inventories and GPR measurements, and area $(\Delta A)$ and mean altitude $(\Delta h)$ change between radar survey and DEM acquisition. For glaciers not included in GI III so far, mean values were calculated

\begin{tabular}{|c|c|c|c|c|c|c|c|}
\hline \multirow{3}{*}{ Glacier name } & \multirow[t]{3}{*}{$\#$} & \multirow[t]{3}{*}{ Points km ${ }^{-2}$} & \multirow{3}{*}{ GPR } & \multicolumn{2}{|l|}{ Year } & \multirow[t]{2}{*}{$\Delta A$} & \multirow[t]{2}{*}{$\Delta h$} \\
\hline & & & & GI II & GI III & & \\
\hline & & & & & & $\mathrm{km}^{2}$ & $\mathrm{~m}$ \\
\hline Alpeiner Ferner & 44 & 13 & 2000 & 1997 & 2006 & -0.065 & -2.1 \\
\hline Bachfallenferner & 29 & 14 & 2000 & 1997 & 2006 & -0.036 & -2.4 \\
\hline Bockkogelkees O & 3 & 5 & 2008 & 1997 & 2006 & -0.064 & -2.3 \\
\hline Brandner Gletscher & 12 & 7 & 2005 & 2002 & & 0.045 & -2.7 \\
\hline Brunnenkogelferner & 15 & 10 & 2000 & 1997 & 2006 & -0.039 & -3.2 \\
\hline Daunkogelferner & 48 & 35 & 1995 & 1997 & 2006 & 0.021 & 1.2 \\
\hline Fernauferner & 98 & 58 & 1999 & 1997 & 2006 & -0.039 & -1.3 \\
\hline Gaisbergferner & 33 & 28 & 1999 & 1997 & 2006 & -0.035 & -1.3 \\
\hline Gaißkarferner & 28 & 55 & 1995 & 1997 & 2006 & 0.028 & 2.0 \\
\hline Gefrorene Wand Kees & 89 & 23 & 1998 & 1999 & 2006 & 0.047 & 0.8 \\
\hline Gepatschferner & 371 & 22 & 2001 & 1997 & 2006 & -0.239 & -2.4 \\
\hline Grinner Ferner & 22 & 320 & 1996 & 1996 & & 0.000 & 0.0 \\
\hline Großes Riepenkees & 34 & 34 & 1998 & 1999 & 2006 & 0.021 & 0.8 \\
\hline Gurglerferner & 100 & 11 & 1998 & 1997 & 2006 & -0.096 & -1.2 \\
\hline Hallstätter Gletscher & 104 & 34 & 2009 & 2002 & & -0.331 & -6.3 \\
\hline Hintereisferner & 145 & 17 & 2001 & 1997 & 2006 & -0.299 & -5.4 \\
\hline Hochalmkees & 130 & 45 & 2001 & 1998 & & -0.131 & -2.7 \\
\hline Hochjochferner & 105 & 15 & 1997 & 1997 & 2006 & 0.000 & 0.0 \\
\hline Hornkees & 85 & 32 & 1999 & 1999 & 2006 & 0.000 & 0.0 \\
\hline Jamtalferner & 61 & 16 & 2005 & 2002 & 2006 & -0.043 & -5.8 \\
\hline Karlesferner & 23 & 16 & 2001 & 1997 & 2006 & -0.042 & -3.4 \\
\hline Kesselwandferner & 213 & 53 & 1995 & 1997 & 2006 & 0.051 & 0.9 \\
\hline Langtaler Ferner & 69 & 24 & 2005 & 1997 & 2006 & -0.245 & -9.6 \\
\hline Lüsener Ferner & 36 & 12 & 2000 & 1997 & 2006 & -0.038 & -2.0 \\
\hline Lüsener Ferner Berglas & 4 & 10 & 2000 & 1997 & 2006 & -0.003 & -1.3 \\
\hline Marzellferner & 40 & 8 & 2002 & 1997 & 2006 & -0.243 & -5.9 \\
\hline Niederjochferner & 38 & 17 & 2002 & 1997 & & -0.165 & -4.5 \\
\hline Nillkees & 25 & 157 & 2006 & 1998 & & -0.019 & -7.2 \\
\hline Obersulzbachkees & 129 & 12 & 2001 & 1998 & & -0.495 & 2.7 \\
\hline Ochsentaler Gletscher & 38 & 15 & 2000 & 2002 & 2004 & 0.021 & 5.0 \\
\hline Ödenwinkelkees & 99 & 48 & 1998 & 1998 & & 0.000 & 0.0 \\
\hline Östlicher Wannetferner & 11 & 19 & 2010 & 1997 & 2006 & 0.052 & -9.5 \\
\hline Pasterze & 178 & 10 & 1998 & 1998 & & 0.000 & 0.0 \\
\hline Rainerkees & 66 & 19 & 2003 & 1998 & & -0.263 & -4.5 \\
\hline Rettenbachferner & 81 & 50 & 2007 & 1997 & 2006 & -0.135 & -8.9 \\
\hline Rotmoosferner & 43 & 15 & 2006 & 1997 & 2006 & -0.357 & -3.8 \\
\hline Schalfferner & 85 & 11 & 2002 & 1997 & 2006 & -0.413 & -6.2 \\
\hline Schaufelferner & 115 & 81 & 1997 & 1997 & 2006 & 0.000 & 0.0 \\
\hline Schladminger Gletscher & 68 & 86 & 2007 & 2002 & & -0.059 & -4.5 \\
\hline Schlatenkees & 58 & 6 & 2001 & 1998 & & -0.419 & -2.7 \\
\hline Schmiedingerkees & 56 & 41 & 2003 & 1998 & & -0.102 & 4.5 \\
\hline Schwarzenberg & 3 & 2 & 2008 & 1997 & 2006 & -0.229 & -7.4 \\
\hline Schwarzensteinkees & 67 & 16 & 1999 & 1999 & 2006 & 0.000 & 0.0 \\
\hline Schwarzmilzferner & 25 & 286 & 2003 & 2000 & 2006 & -0.011 & 0.0 \\
\hline Sexegerten & 15 & 7 & 2010 & 1997 & 2006 & -0.280 & -8.8 \\
\hline Sonnblickkees & 82 & 56 & 1998 & 1998 & & 0.000 & 0.0 \\
\hline Sulzenauferner & 30 & 7 & 2003 & 1997 & 2006 & -0.049 & -3.8 \\
\hline Sulztalferner & 52 & 13 & 2001 & 1997 & 2006 & -0.141 & -2.3 \\
\hline Taschachferner W & 80 & 13 & 2003 & 1997 & 2006 & -0.435 & -4.1 \\
\hline Tiefenbachferner & 74 & 67 & 2007 & 1997 & 2006 & -0.121 & -7.6 \\
\hline Tisenjochferner & 29 & 121 & 1997 & 1997 & & 0.000 & 0.0 \\
\hline Umbalkees & 116 & 25 & 2003 & 1998 & & -0.355 & -4.5 \\
\hline Untersulzbachkees & 36 & 10 & 2001 & 1998 & & -0.002 & -2.7 \\
\hline Vermuntgletscher & 34 & 18 & 2000 & 2002 & 2004 & 0.052 & 4.1 \\
\hline Vernagtferner & 56 & 6 & 2002 & 1997 & 2006 & -0.320 & -5.2 \\
\hline Viltragenkees & 32 & 15 & 2010 & 1998 & & -0.383 & -10.8 \\
\hline Vorderer Ölgrubenferner & 8 & 17 & 2010 & 1997 & & 0.000 & -11.7 \\
\hline
\end{tabular}



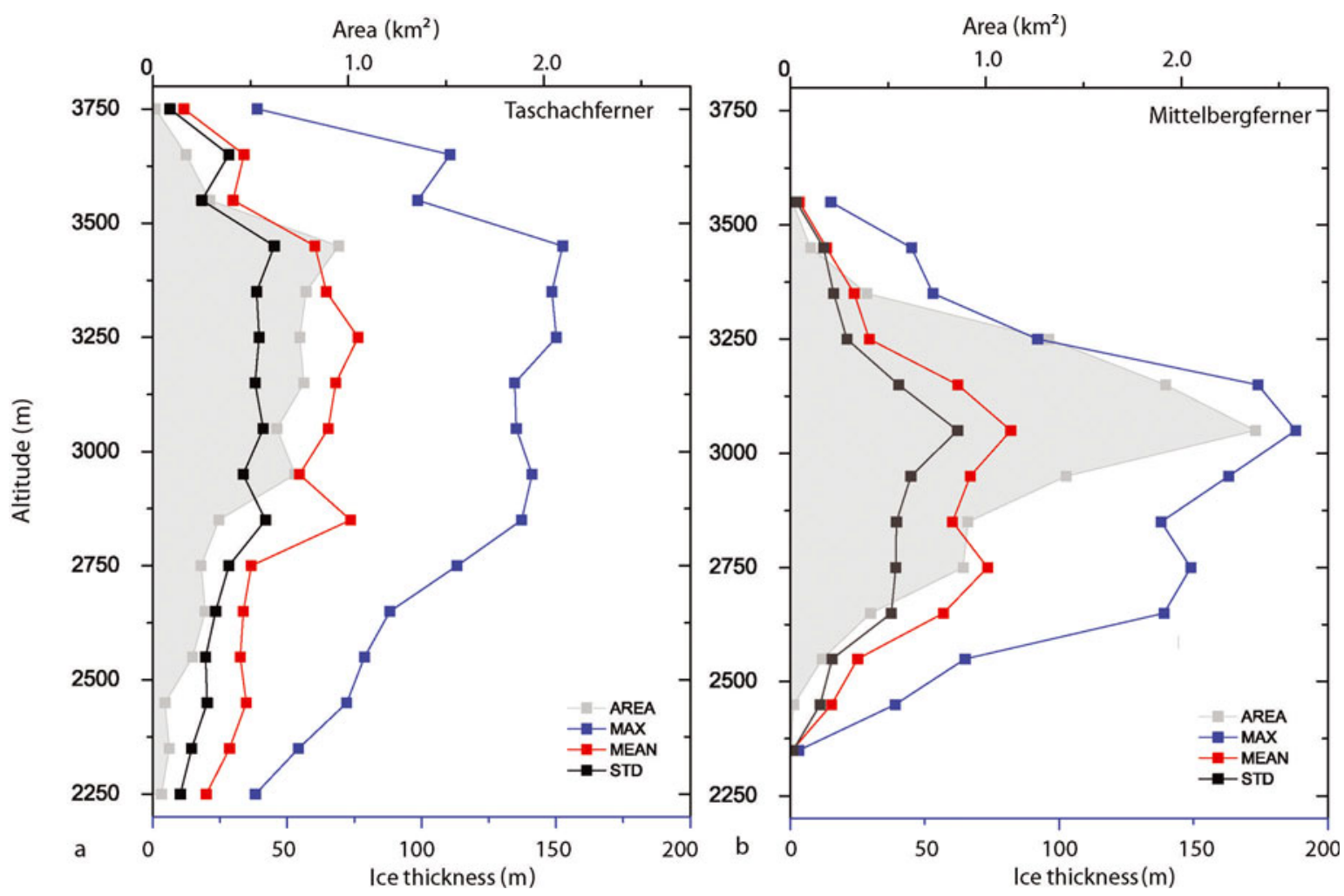

Fig. 7. Mean and maximum ice thickness and glacier area in different altitude zones of Taschachferner and Mittelbergferner.

Abermann and others (2009) estimate $\sigma_{A} / A$ as $\pm 1.5 \%$ for glaciers larger than $1 \mathrm{~km}^{2}$, and $\pm 5.0 \%$ for smaller glaciers. With the uncertainty of the mean ice thickness given above, the volume uncertainty is calculated in Table 2.

\section{RESULTS AND DISCUSSION}

For all 64 glaciers surveyed between 1995 and 2010 (Table 1) the measured data were interpolated to the total glacier area as described above. The number and spatial distribution of the measurements differ between glaciers as a result of accessibility. In crevassed areas, risky glacier travel and multiple reflections prohibited the survey. On and close to steep slopes, avalanches were a major concern, as well as fixing the antennas to the glacier surface. Figures 2 and 3 show the data recorded on Taschachferner and Mittelbergferner as typical examples of the data distribution. On Mittelbergferner, profiles along and across the glacier were measured. On Taschachferner, large crevasse zones and steep slopes prevented measurement along a central flowline. Manual interpolation of the contours of bedrock topography allowed the estimated ice thicknesses at the vertical ice walls to be included and suggests that the crevasse zones are the result of a bedrock ridge (Fig. 2).

The surveyed glaciers cover areas of $0.001-18.4 \mathrm{~km}^{2}$. The mean thickness ranges from 10 to $92 \mathrm{~m}$, and the maximum ice thickness from 26 to $311 \mathrm{~m}$. For each surveyed glacier, area, mean and maximum ice thickness and the total volume are listed in Table 3. In total, the 64 glaciers cover an area of $223.3 \pm 3.6 \mathrm{~km}^{2}$ and contain a volume of $11.2 \pm 1.1 \mathrm{~km}^{3}$. This would correspond to an average ice thickness of $50 \pm 3 \mathrm{~m}$ if the ice were equally distributed.

Not only the total volume, but also the ice thickness distribution was calculated for all glaciers. The ice thickness maps of Mittelbergferner and Taschachferner are shown in Figure 4. Ice divides and glacier areas were assumed to be the same as in the glacier inventory to allow comparisons on a glacier-to-glacier basis. The ice divides in this study are therefore not considered to be flow divides but the glacier surface water divides mapped in the 1969 glacier inventory.

All spatial data were calculated in a very dense grid, although similar studies have used a spatial resolution of $25 \mathrm{~m}$ (Farinotti and others, 2009a). In this study, a nominal resolution of $5 \times 5 \mathrm{~m}$ was chosen to avoid artefacts caused by different grid sizes used for the surface and bedrock DEM. The spatial resolution of the data differs from glacier to glacier, dependent on the number and distribution of ice thickness measurements. A grid size between $100 \times 100 \mathrm{~m}^{2}$ and $250 \times 250 \mathrm{~m}^{2}$ would thus have been more appropriate, but would then have resulted in mismatches with the glacier inventory data, especially for smaller glaciers. For most glaciers, the ice thickness data do not allow calculation of potential subsurface glacier lakes or routing of subglacial water flows. For specific analysis of features of the subglacial topography, higher data density and, to retrieve a higher spatial resolution of the subglacial topography, higher frequencies/smaller antenna footprints are recommended. Products of the compiled GPR data useful for glaciological application are, for example, altitudinal distributions of the ice volume, as shown for Mittelbergferner and Taschachferner in Figure 7.

The number and distribution of survey points was governed by the topography of the glaciers, but since the thickest parts of the glaciers are usually located in flat areas with few crevasses, the maximum ice thickness will have been recorded for each glacier. Steep and crevassed areas usually show thinner ice cover. In some locations, the spatial coverage could be improved by helicopter surveys. In areas subject to multiple reflections (e.g. crevassed areas 
Table 3. Areas, $A$ (GI II), mean ice thickness, $h$ (GI II), and volumes, V (GI II), calculated from the GPR data and corrected for area and volume change between the GPR measurements and the glacier inventory. The maximum ice thickness was not corrected with the local thickness change since that is not available for every glacier. The uncertainty of the maximum ice thickness, $h_{\max }(\mathrm{GPR})$, is therefore higher, to correspond to the Gl II volume data

\begin{tabular}{|c|c|c|c|c|c|}
\hline \multirow[t]{2}{*}{ Glacier name } & \multirow{2}{*}{$\begin{array}{c}A(\mathrm{Gl} \mathrm{II}) \\
\mathrm{km}^{2}\end{array}$} & \multirow{2}{*}{$\begin{array}{c}h(\mathrm{GI} I \mathrm{I}) \\
\mathrm{m}\end{array}$} & \multicolumn{2}{|c|}{$V(\mathrm{Gl} \mathrm{II})$} & \multirow{2}{*}{$\begin{array}{c}h_{\max }(\mathrm{GPR}) \\
\mathrm{m}\end{array}$} \\
\hline & & & $\mathrm{km}^{3}$ & $\%$ & \\
\hline Alpeiner Ferner & $3.406 \pm 0.051$ & $51 \pm 10$ & $0.174 \pm 0.035$ & 21 & $163 \pm 12$ \\
\hline Bachfallenferner & $2.084 \pm 0.031$ & $41 \pm 7$ & $0.086 \pm 0.015$ & 19 & $97 \pm 10$ \\
\hline Bockkogelkees O & $0.635 \pm 0.032$ & $42 \pm 16$ & $0.027 \pm 0.010$ & 40 & $87 \pm 18$ \\
\hline Bockkogelkees W & $0.522 \pm 0.026$ & $73 \pm 29$ & $0.038 \pm 0.015$ & 42 & $69 \pm 33$ \\
\hline Brandner Gletscher & $1.651 \pm 0.025$ & $19 \pm 5$ & $0.031 \pm 0.009$ & 34 & $74 \pm 8$ \\
\hline Brunnenkogelferner & $1.524 \pm 0.023$ & $27 \pm 7$ & $0.041 \pm 0.010$ & 28 & $56 \pm 10$ \\
\hline Daunkogelferner & $1.376 \pm 0.021$ & $42 \pm 4$ & $0.057 \pm 0.005$ & 9 & $107 \pm 5$ \\
\hline Fernauferner & $1.693 \pm 0.025$ & $37 \pm 5$ & $0.063 \pm 0.009$ & 15 & $178 \pm 6$ \\
\hline Gaisbergferner & $1.191 \pm 0.018$ & $34 \pm 2$ & $0.041 \pm 0.003$ & 7 & $99 \pm 4$ \\
\hline Gaißkarferner & $0.514 \pm 0.026$ & $39 \pm 6$ & $0.020 \pm 0.003$ & 15 & $108 \pm 8$ \\
\hline Gefrorene Wand Kees & $3.818 \pm 0.057$ & $34 \pm 2$ & $0.130 \pm 0.008$ & 6 & $124 \pm 3$ \\
\hline Gepatschferner & $17.16 \pm 0.257$ & $94 \pm 5$ & $1.618 \pm 0.089$ & 6 & $221 \pm 7$ \\
\hline Grießkogel & $0.429 \pm 0.021$ & $20 \pm 6$ & $0.008 \pm 0.003$ & 45 & $55 \pm 12$ \\
\hline Grinner Ferner & $0.069 \pm 0.003$ & $11 \pm 8$ & $0.001 \pm 0.001$ & 80 & $32 \pm 8$ \\
\hline Großes Riepenkees & $0.989 \pm 0.049$ & $25 \pm 2$ & $0.025 \pm 0.003$ & 10 & $76 \pm 3$ \\
\hline Gurglerferner & $9.379 \pm 1.141$ & $59 \pm 15$ & $0.555 \pm 0.142$ & 26 & $201 \pm 16$ \\
\hline Hallstätter Gletscher & $3.041 \pm 0.046$ & $55 \pm 4$ & $0.164 \pm 0.013$ & 9 & $131 \pm 10$ \\
\hline Hintereisferner & $8.55 \pm 0.128$ & $67 \pm 7$ & $0.573 \pm 0.063$ & 12 & $242 \pm 13$ \\
\hline Hochalmkees & $2.907 \pm 0.044$ & $53 \pm 6$ & $0.152 \pm 0.016$ & 11 & $155 \pm 8$ \\
\hline Hochjochferner & $6.829 \pm 0.102$ & $36 \pm 6$ & $0.246 \pm 0.038$ & 15 & $100 \pm 6$ \\
\hline Hornkees & $2.665 \pm 0.040$ & $28 \pm 2$ & $0.075 \pm 0.006$ & 8 & $111 \pm 2$ \\
\hline Jamtalferner & $3.712 \pm 0.056$ & $52 \pm 6$ & $0.192 \pm 0.022$ & 13 & $119 \pm 12$ \\
\hline Karlesferner & $1.457 \pm 0.022$ & $26 \pm 3$ & $0.038 \pm 0.005$ & 15 & $70 \pm 7$ \\
\hline Kesselwandferner & $4.052 \pm 0.061$ & $79 \pm 11$ & $0.320 \pm 0.043$ & 13 & $155 \pm 11$ \\
\hline Langtaler Ferner & $2.894 \pm 0.043$ & $56 \pm 3$ & $0.156 \pm 0.008$ & 6 & $147 \pm 12$ \\
\hline Lüsener Ferner & $3.105 \pm 0.047$ & $58 \pm 13$ & $0.180 \pm 0.042$ & 24 & $131 \pm 15$ \\
\hline Lüsener Ferner Berglas & $0.395 \pm 0.020$ & $79 \pm 21$ & $0.031 \pm 0.009$ & 28 & $131 \pm 23$ \\
\hline Marzellferner & $4.885 \pm 0.073$ & $52 \pm 15$ & $0.251 \pm 0.071$ & 32 & $187 \pm 20$ \\
\hline Mittelbergferner & $9.916 \pm 0.149$ & $53 \pm 11$ & $0.526 \pm 0.114$ & 22 & $188 \pm 13$ \\
\hline Mullwitzkees & $3.229 \pm 0.048$ & $39 \pm 9$ & $0.122 \pm 0.029$ & 26 & $78 \pm 13$ \\
\hline Niederjochferner & $2.204 \pm 0.033$ & $31 \pm 3$ & $0.066 \pm 0.006$ & 11 & $98 \pm 7$ \\
\hline Nillkees & $0.159 \pm 0.008$ & $22 \pm 6$ & $0.003 \pm 0.001$ & 40 & $42 \pm 13$ \\
\hline Obersulzbachkees & $11.01 \pm 0.165$ & $40 \pm 10$ & $0.446 \pm 0.112$ & 24 & $208 \pm 13$ \\
\hline Ochsentaler Gletscher & $2.523 \pm 0.038$ & $44 \pm 8$ & $0.111 \pm 0.020$ & 16 & $163 \pm 13$ \\
\hline Ödenwinkelkees & $2.062 \pm 0.031$ & $50 \pm 6$ & $0.103 \pm 0.012$ & 12 & $167 \pm 6$ \\
\hline Östlicher Wannetferner & $0.571 \pm 0.029$ & $28 \pm 1$ & $0.017 \pm 0.001$ & 8 & $85 \pm 13$ \\
\hline Pasterze & $18.38 \pm 0.276$ & $82 \pm 23$ & $1.507 \pm 0.426$ & 28 & $311 \pm 6$ \\
\hline Rainerkees & $3.511 \pm 0.053$ & $43 \pm 3$ & $0.148 \pm 0.009$ & 8 & $78 \pm 11$ \\
\hline Rettenbachferner & $1.604 \pm 0.024$ & $30 \pm 3$ & $0.045 \pm 0.005$ & 13 & $62 \pm 8$ \\
\hline Rotmoosferner & $2.878 \pm 0.043$ & $32 \pm 5$ & $0.089 \pm 0.013$ & 16 & $104 \pm 8$ \\
\hline Schalfferner & $7.656 \pm 0.115$ & $50 \pm 11$ & $0.379 \pm 0.084$ & 25 & $117 \pm 17$ \\
\hline Schaufelferner & $1.419 \pm 0.021$ & $26 \pm 5$ & $0.037 \pm 0.007$ & 20 & $94 \pm 5$ \\
\hline Schladminger Gletscher & $0.794 \pm 0.040$ & $45 \pm 9$ & $0.035 \pm 0.007$ & 22 & $131 \pm 13$ \\
\hline Schlatenkees & $9.321 \pm 0.140$ & $58 \pm 20$ & $0.536 \pm 0.185$ & 36 & $197 \pm 22$ \\
\hline Schmiedingerkees & $1.367 \pm 0.021$ & $19 \pm 2$ & $0.026 \pm 0.003$ & 10 & $70 \pm 7$ \\
\hline Schwarzenberg & $1.552 \pm 0.023$ & $40 \pm 15$ & $0.059 \pm 0.023$ & 46 & $107 \pm 22$ \\
\hline Schwarzensteinkees & $4.126 \pm 0.062$ & $32 \pm 4$ & $0.132 \pm 0.018$ & 14 & $94 \pm 4$ \\
\hline Schwarzmilzferner & $0.087 \pm 0.004$ & $12 \pm 9$ & $0.001 \pm 0.001$ & 72 & $35 \pm 9$ \\
\hline Sexegerten & $2.157 \pm 0.032$ & $35 \pm 9$ & $0.070 \pm 0.019$ & 34 & $93 \pm 18$ \\
\hline Sonnblickkees & $1.474 \pm 0.022$ & $35 \pm 5$ & $0.052 \pm 0.007$ & 14 & $142 \pm 5$ \\
\hline Sulzenauferner & $4.501 \pm 0.068$ & $49 \pm 16$ & $0.219 \pm 0.071$ & 35 & $151 \pm 20$ \\
\hline Sulztalferner & $3.986 \pm 0.060$ & $42 \pm 8$ & $0.168 \pm 0.033$ & 21 & $131 \pm 11$ \\
\hline Taschachferner W & $6.366 \pm 0.095$ & $62 \pm 13$ & $0.392 \pm 0.040$ & 22 & $153 \pm 17$ \\
\hline Tiefenbachferner & $1.109 \pm 0.017$ & $42 \pm 6$ & $0.044 \pm 0.006$ & 17 & $82 \pm 13$ \\
\hline Tisenjochferner & $0.24 \pm 0.012$ & $10 \pm 3$ & $0.002 \pm 0.001$ & 31 & $26 \pm 3$ \\
\hline Umbalkees & $4.729 \pm 0.071$ & $46 \pm 3$ & $0.212 \pm 0.012$ & 6 & $110 \pm 7$ \\
\hline Untersulzbachkees & $3.723 \pm 0.056$ & $94 \pm 26$ & $0.349 \pm 0.096$ & 28 & $219 \pm 28$ \\
\hline Vermuntgletscher & $1.843 \pm 0.028$ & $20 \pm 2$ & $0.036 \pm 0.004$ & 9 & $62 \pm 6$ \\
\hline Vernagtferner & $8.839 \pm 0.133$ & $42 \pm 13$ & $0.370 \pm 0.117$ & 36 & $134 \pm 18$ \\
\hline Viltragenkees & $2.128 \pm 0.032$ & $39 \pm 5$ & $0.074 \pm 0.010$ & 16 & $129 \pm 15$ \\
\hline Vord. Ölgrubenferner & $0.48 \pm 0.024$ & $28 \pm 2$ & $0.013 \pm 0.001$ & 13 & $67 \pm 14$ \\
\hline Waxeggkees & $3.346 \pm 0.050$ & $30 \pm 8$ & $0.099 \pm 0.028$ & 30 & $83 \pm 10$ \\
\hline Weißseeferner & $2.697 \pm 0.040$ & $31 \pm 10$ & $0.084 \pm 0.027$ & 32 & $80 \pm 11$ \\
\hline Windacher Ferner & $0.389 \pm 0.019$ & $27 \pm 4$ & $0.010 \pm 0.002$ & 17 & $74 \pm 8$ \\
\hline
\end{tabular}


or areas close to bedrock), airborne radar cannot be expected to perform automatically better than ground-based measurements.

The comparison of the altitudinal distribution of ice thickness in Figure 7 demonstrates that the altitude zones with the highest mean and maximum ice thickness may differ from the zones with the largest areas. Therefore, including at least the vertical distribution of ice thickness should improve the reliability of future glacier area and volume change scenarios.

\section{CONCLUSIONS AND OUTLOOK}

Nearly two decades of GPR surveys have allowed the calculation of ice thickness data for a regional glacier sample. The data will be further extrapolated to compile a regional volume inventory. The resulting volume of $11.2 \pm 1.1 \mathrm{~km}^{3}$ and the mean ice thickness of $50 \mathrm{~m}$ will then be extrapolated to the total Austrian glacier area, which is about twice that of the surveyed area. The surveys included a large portion of the largest glaciers, but also smaller glaciers, to be representative of Austria's glaciers. The glaciers not measured to date are either small, difficult to access, steep or crevassed. Further investigations will focus on the best method for extrapolating these data. Algorithms as presented by Farinotti and others (2009a) and Huss and Farinotti (in press) are valuable approaches to modeling regional gridded ice thickness data. The data presented in this study can also be used as validation data for these algorithms. For example, the ice thickness data could help to investigate the effect of different glacier inventory dates, which is of special concern in current glacier retreat. The strength of the presented data lies in the fact that glacier areas, surface elevations and ice thickness data are derived consistently on the basis of the same dataset and recorded within a few years.

\section{ACKNOWLEDGEMENTS}

N. Span, M. Butschek, J. Lang, M. Massimo and S. Erhart carried out part of the GPR measurements. This work would not have been possible without the many helpers during several years of campaigns. K. Helfricht and M. Stocker helped with data processing. The field campaigns on Austrian glaciers were funded by the Commission of Geophysical Research, Austrian Academy of Sciences.

\section{REFERENCES}

Abermann J, Lambrecht A, Fischer A and Kuhn M (2009) Quantifying changes and trends in the glacier area and volume in the Austrian Öztal Alps (1969-1997-2006). Cryosphere, 3(2), 205-215 (doi: 10.5194/tc-3-205-2009)

Abermann J, Seiser B, Meran I, Stocker-Waldhuber M, Goller M and Fischer A (2012) A new ALS glacier inventory of North Tyrol, Austria, for 2006. Z. Gletscherkd. Glazialgeol., 43-44, 109-119

Arendt AA, Echelmeyer KA, Harrison WD, Lingle CS and Valentine VB (2002) Rapid wastage of Alaska glaciers and their contribution to rising sea level. Science, 297(5580), 382-386 (doi: 10.1126/science.1072497)

Bauder A (2001) Bestimmung der Massenbilanz von Gletschern mit Fernerkundungsmethoden und Fliessmodellierungen: eine Sensitivitätsstudie auf dem Unteraargletscher. Mitt. VAW/ETH 169

Binder D, Brückl E, Roch KH, Behm M, Schöner W and Hynek B (2009) Determination of total ice volume and ice-thickness distribution of two glaciers in the Hohe Tauern region, Eastern Alps, from GPR data. Ann. Glaciol., 50(51), 71-79 (doi: 10.3189/172756409789097522)

Casassa G, López P, Pouyard B and Escobar F (2009) Detection of changes in glacial run-off in alpine basins: examples from North America, the Alps, central Asia and the Andes. Hydrol. Process., 23(1), 31-41 (doi: 10.1002/hyp.7194)

Farinotti D, Huss M, Bauder A, Funk M and Truffer M (2009a) A method to estimate ice volume and ice-thickness distribution of alpine glaciers. J. Glaciol., 55(191), 422-430 (doi: 10.3189/ 002214309788816759)

Farinotti D, Huss M, Bauder A and Funk M (2009b) An estimate of the glacier ice volume in the Swiss Alps. Global Planet. Change, 68(3), 225-231 (doi: 10.1016/j.gloplacha.2009.05.004)

Fischer A (2009) Calculation of glacier volume from sparse icethickness data, applied to Schaufelferner, Austria. J. Glaciol., 55(191), 453-460 (doi: 10.3189/002214309788816740)

Fischer A, Olefs M and Abermann J (2011) Glaciers, snow and ski tourism in Austria's changing climate. Ann. Glaciol., 52(58), 89-96 (doi: 10.3189/172756411797252338)

Fischer N, Span M, Kuhn M, Massimo M and Butschek M (2007) Radarmessungen der Eisdicke Österreichischer Gletscher. Band II: Messungen 1999 bis 2006. Österreich. Beitr. Meteorol. Geophys. 39

Haeberli W, Wächter HP, Schmid W and Sidler C (1982) Erste Erfahrungen mit dem US Geological Survey - Monopuls Radioecholot im Firn, Eis und Permafrost der Schweizer Alpen. Arb. VAW/ETH 6

Huss $M$ and Farinotti $D$ (in press) Distributed ice thickness and volume of 180,000 glaciers around the globe. J. Geophys. Res.,117(F4), F04010 (doi: 10.1029/2012JF002523)

Huss M, Farinotti D, Bauder A and Funk M (2008) Modelling runoff from highly glacierized alpine drainage basins in a changing climate. Hydrol. Process., 22(19), 3888-3902 (doi: 10.1002/ hyp.7055)

Hutchinson MF (1989) A new procedure for gridding elevation and stream line data with automatic removal of spurious pits. J. Hydrol., 106(3-4), 211-232 (doi: 10.1016/0022-1694(89) 90073-5)

Jansson P, Hock R and Schneider T (2003) The concept of glacier storage: a review. J. Hydrol., 282(1-4), 116-129 (doi: 10.1016/ S0022-1694(03)00258-0)

Kaser G, Grosshauser M and Marzeion B (2010) Contribution potential of glaciers to water availability in different climate regimes. Proc. Natl Acad. Sci. USA (PNAS), 107(47), 20 223-20 227 (doi: 10.1073/pnas.1008162107)

Kuhn MH and Escher-Vetter H (2004) Die Reaktion der osterreichischen Gletscher und ihres Abflusses auf Anderungen von Temperatur und Niederschlag. Österreich. Wasser. Abfallwirtsch., 56(1-2), 1-7

Kuhn M and Fischer A (2012) Preliminary ice volumes of 64 Austrian glaciers based on ground penetrating radar measurements from 1996 to 2006. Z. Gletscherkd. Glazialgeol., 43-44, 121-177

Kuhn M, Lambrecht A, Abermann J, Patzelt G and Gross G (2009) Die österreichischen Gletscher 1998 und 1969, Flächen- und Volumenänderungen. (Landesverteidigungsakademie, Bundesministerium für Landesverteidigung Projektbericht 10) Österreichische Akademie der Wissenschaften, Wien

Kuhn M, Lambrecht A, Abermann J, Patzelt G and Gross G (2012) The Austrian glaciers 1998 and 1969, area and volume changes. Z. Gletscherkd. Glazialgeol., 43-44, 3-107

Lambrecht A and Kuhn M (2007) Glacier changes in the Austrian Alps during the last three decades, derived from the new Austrian glacier inventory. Ann. Glaciol., 46, 177-184 (doi: 10.3189/172756407782871341)

Lemke P and 10 others (2007) Observations: changes in snow, ice and frozen ground. In Solomon S and 7 others eds. Climate change 2007: the physical science basis. Contribution of Working Group I to the Fourth Assessment Report of the 
Intergovernmental Panel on Climate Change. Cambridge University Press, Cambridge, 339-383

Müller F, Caflisch T and Müller G (1976) Firn und Eis der Schweizer Alpen: Gletscherinventar. (Geographisches Institut Publ. 57) ETH, Zürich

Müller F, Caflisch T and Müller G (1977) Instructions for the compilation and assemblage of data for a world glacier inventory. Temporal Technical Secretariat for the World Glacier Inventory, ETH, Zürich

Narod BB and Clarke GKC (1994) Miniature high-power impulse transmitter for radio-echo sounding. J. Glaciol., 40(134), 190194

Radić V and Hock R (2011) Regionally differentiated contribution of mountain glaciers and ice caps to future sea-level rise. Nature Geosci., 4(2), 91-94 (doi: 10.1038/ngeo1052)

Raper SCB and Braithwaite RJ (2006) Low sea level rise projections from mountain glaciers and icecaps under global warming. Nature, 439(7074), 311-313 (doi: 10.1038/nature04448)

Rose GC and Vickers RS (1974) Calculated and experimental response of resistively loaded $\mathrm{V}$ antennas to impulsive excitation. Int. J. Electron., 37(2), 261-271 (doi: 10.1080/ 00207217408900519)

Span N, Fischer A, Kuhn M, Massimo M and Butschek M (2005) Radarmessungen der Eisdicke Österreichischer Gletscher. Band 1 Messungen 1995 bis 1998. Österreich. Beitr. Meteorol. Geophys. 33

Stocker-Waldhuber M, Wiesenegger H, Abermann J, Hynek B and Fischer A (2012) A new glacier inventory of the province of Salzburg, Austria 2007/2009. Z. Gletscherkd. Glazialgeol., 43-44, 121-128

World Glacier Monitoring Service (WGMS) (1989) World glacier inventory: status 1988, ed. Haeberli W., Bösch H, Scherler K, Østrem G and Wallén C. IAHS (ICSI)/UNEP/UNESCO, World Glacier Monitoring Service, Zürich.

Wu T and King R (1965) The cylindrical antenna with nonreflecting resistive loading. IEEE Trans. Antennas Propag., 13(3), 369-373 (doi: 10.1109/TAP.1965.1138429)

Zemp M, Haeberli W, Hoelzle M and Paul F (2006) Alpine glaciers to disappear within decades? Geophys. Res. Lett., 33(13), L13504 (doi: 10.1029/2006GL026319) 